\title{
KEDEWASAAN DALAM PERUBAHAN UNDANG-UNDANG BATAS USIA PERKAWIANAN
}

\author{
Gusti Muhammad Andre \\ Universitas Islam Sultan Agung Semarang \\ Email: gustiandre0209@gmail.com \\ Mohammad Noviani Ardi \\ Universitas Islam Sultan Agung Semarang \\ Email: mn.ardi@unissula.ac.id \\ DOI: 10.37876/adhki.v2i2.51
}

\begin{abstract}
This study aims to determine the age limit for adulthood in carrying out marriage through a psychological perspective based on the amendment of Law No. 1 of 1974 to Law No. 16 of 2019. The benefit of this research is to find out how the ideal adult age limit in carrying out marriage and also know how early marriage impacts. This research method uses a qualitative descriptive analysis approach in which data collection techniques are used through interviews which are then compiled and reported and then drawn logical conclusions. The subjects in this study were several members of the Central Java HIMPSI (Indonesian Psychological Association). The results of this study can be concluded in the form of the ideal age limit in carrying out marriage through the HIMPSI perspective, namely the age of 21-25 years because at that age the prospective bride and groom are mature from the aspects of health, cognitive, emotional, social, educational and economic.
\end{abstract}

Keywords: Laws Changes, Adulty, Psychology

\begin{abstract}
Abstrak
Penelitian ini bertujuan untuk mengetahui batas usia kedewasaan dalam melaksanakan perkawinan melalui perspektif psikologi berdasarkan dengan perubahan Undang-Undang No 1 Tahun 1974 menjadi Undang-Undang No 16 Tahun 2019. Manfaat penelitian ini dapat mengetahui bagaimana batas usia dewasa yang ideal dalam melaksanakan perkawinan dan juga mengetahui bagaimana dampak dari perkawinan dini. Metode penelitian ini menggunakan deskriptif kualitatif dengan pendekatan analisis yang teknik pengumpulan datanya melalui wawancara yang kemudian disusun dan dilaporkan kemudian ditarik kesimpulan yang logis. Subjek dalam penelitian ini adalah beberapa anggota HIMPSI (Himpunan Psikologi Indonesia) Jawa Tengah. Hasil dari penelitian ini dapat dapat disimpulkan berupa batas usia yang ideal dalam melaksanakan perkawinan melalui perspektif HIMPSI, yaitu usia 21-25 tahun karena pada usia tersebut calon pengantin sudah matang dari aspek kesehatan,, kognitif, emosional, sosial, pendidikan dan ekonomi.
\end{abstract}

Kata Kunci: Perubahan Undang-Undang, Kedewasaan, Psikologi

\section{Pendahuluan}

Perkawinan adalah suatu akad antara laki-laki dan perempuan yang bersifat luhur dan suci yang menjadi sebab sahnya sebagai suami istri dan melalui perkawinan menjadikan dihalalkannya hubungan seksual antara keduanya dengan tujuan mencapai keluarga yang penuh kasih sayang, kebajikan dan saling menyantuni satu sama lain sehingga tercipta keluarga yang sakinah, mawaddah dan warahmah. ${ }^{1}$ Untuk mendukung tercapainya perkawinan yang baik, tidak terlepas dari tujuan sebuah perkawinan yaitu

\footnotetext{
${ }^{1}$ Sudarsono, Hukum Perkawinan Nasional (Jakarta: PT. Renika Cipta, 1991), p.2.
} 
membentuk keluarga yang sejahtera, harmonis, kekal sehingga terciptanya rumah tangga yang baik tanpa berakhir dengan perceraian. Maka dalam menyelesaikan masalah perkawinan, dapat diketahui dari segi kematangan usia calon pengantin lakilaki maupun perempuan, karena kematangan usia merupakan suatu sebab untuk terciptanya sebuah akumulasi kesiapan fisik, ekonomi, sosial, mental kejiwaan, agama dan budaya. ${ }^{2}$

Di antara problematika di dalam perkawinan adalah praktik perkawinan usia dini. Praktik perkawinan usia dini telah menimbulkan keresahan bagi masyarakat yang mengakibatkan kualitas rumah tangga tidak dalam performa yang baik dari aspek reproduksi, kesiapan psikologis, pendidikan dan ekonomi. Berdasarkan data survei Unite For Children (UNICEF) di Indonesia pada Januari sampai Juni 2020, terdapat 34.000 permohonan dispensasi perkawinan usia dini yang diajukan ke Pengadilan Agama. 97\% di antaranya dikabulkan oleh Pengadilan Agama. Padahal sepanjang 2019 hanya terdapat 23.700 permohonan. ${ }^{3}$

Adapun faktor yang mempengaruhi perkawinan usia dini antara lain: pendidikan, orang tua, ekonomi, sosial, budaya, keinginan sendiri dan Marrieged By Acident (MBA). Berdasarkan beberapa faktor tersebut, maka timbullah dampak yaitu rentannya Kekerasan Dalam Rumah Tangga (KDRT) yang berujung pada perceraian. ${ }^{4}$ Sehingga hal inilah yang menjadi salah satu sebab bahwa pemerintah meningkatkan batas usia perkawinan di dalam perubahan Undang-Undang Perkawinan.

Undang-Undang perkawinan menyebutkan bahwa usia minimal dalam melaksanakan perkawinan bagi calon suami dan calon istri diatur dalam perubahan Undang-Undang pasal 7 ayat (1) Undang-Undang No 1 Tahun 1974 Perkawinan. Adapun perubahan yang telah disahkan oleh Dewan Perwakilan Rakyat (DPR) adalah Undang-Undang No 16 Tahun 2019 menyatakan bahwa perkawinan dapat diizinkan hanya apabila laki-laki dan perempuan telah mencapai usia 19 tahun. Sehingga Mahkamah Konstitusi mengeluarkan putusan No 22 /PUU-XV/2017 yang berkaitan dengan gugatan uji material terhadap Undang-Undang tersebut menetapkan bahwa di Negara Kesatuan Republik Indonesia (NKRI) untuk melaksanakan perkawinan bagi laki-laki maupun perempuan adalah usia 19 tahun. ${ }^{5}$ Namun perubahan Undang-Undang ini perlu dikaji kembali mengenai landasan psikologi. Karena perubahan perUndang-Undangan tentang batas usia perkawinan ini tidak terlepas dari beberapa aspek seperti kesehatan, kognitif, emosional, sosial, pendidikan dan ekonomi.

Mengenai kedewasaan dan kematangan usia seseorang, dapat diketahui melalui pendekatan ilmu psikologi, ilmu psikologi merupakan suatu ilmu tentang hakikat jiwa dan tentang prosesnya sampai akhir. ${ }^{6}$ Kedewasaan akan selalu berkembang melalui

${ }^{2}$ Ahmad Tholabi Karlie, Hukum Keluarga Indonesia (Jakarta: Sinar Grafika, 2013), p.204.

3 Pusparisa Yosepha, "Jutaan Anak Perempuan Lakukan Permnikahan Dini," 2020, https://databoks.katadata.co.id/datapublish/2020/09/11/jutaan-anak-perempuan-indonesia-lakukanpernikahan-dini.

4 Fachria Octaviani, "DAMPAK PERNIKAHAN USIA DINI TERHADAP PERCERAIAN DI INDONESIA," 2021, p., https://journal.unpas.ac.id/index.php/humanitas/article/view/2820/138740.

5 Ali Akbar, "Landasan Filosofis Dalam Dispensasi Nikah Dalam Uu No. 16 Tahun 2019," Journal of Chemical Information and Modeling 53, no. 1-24 (2019): ,pp., 1-2.

${ }^{6}$ Abdul Rahman Shaleh, Psikologi Suatu Pengantar Dalam Presfektif Islam (Jakarta: Prenada Kencana, 2019), ,pp.5. 
kematangan mental, kepribadian, pola pikir dan perilaku sosial. Selain itu perlu diketahui bahwa perkembangan kedewasaan berkaitan juga dengan perkembangan usia dan fisik. ${ }^{7}$

Berdasarkan uraian penjelasan di atas antara revisi Undang-Undang perkawinan dan ilmu psikologi terdapat adanya celah untuk penelitian dalam hal batas usia kedewasaan untuk melaksanakan perkawinan. Oleh karena itu peneliti akan melakukan suatu penelitian untuk menganalisis berkenaan dengan batas usia perkawinan dalam perubahan Undang-Undang No 16 Tahun 2019 dan dampaknya dalam perspektif ilmu psikologi berdasarkan wawancara dengan Himpunan Psikologi Indonesia (HIMPSI). Dalam hal ini penulis mengangkat sebuah judul skripsi yaitu pandangan HIMPSI Jawa Tengah terhadap perubahan batas usia perkawinan (Studi atas Undang-Undang No 16 Tahun 2019 tentang perubahan Undang-Undang No 1 Tahun 1974).

\section{Metode Penelitian}

Penelitian ini bersifat deskriptif kualitatif, yaitu penelitian yang menggambarkan keadaan yang sebenarnya. Untuk memperoleh data yang objektif, maka dapat dilakukan penelitian lapangan (field research). Penelitian ini menggunakan pendekatan perspektif dimana pengumpulan data dilakukan secara langsung di lapangan dengan melakukan wawancara kepada Himpunan Psikologi Indonesia Jawa Tengah (HIMPSI).

Sumber data yang di perlukan dalam penelitian ini disesuaikan dengan judulnya yaitu kedewasaan dalam perubahan Undang-Undang batas usia perkawianan perspektif HIMPSI Jawa Tengah. Data primer dalam penelitian ini berasal dari pihak yang bersangkutan dan diperoleh melalui wawancara dengan subjek penelitian dan informan. Dalam penelitian ini subjek penelitian ini adalah Himpunan Psikologi Indonesia Jawa Tengah (HIMPSI). Sedangkan objek penelitian ini adalah perubahan batas usia perkawinan dalam Undang-Undang No 16 Tahun 2019 tentang perubahan atas Undang-Undang No 1 Tahun 1974 tentang batas usia perkawinan. Sehingga dapat diketahui bagaimana perspektif HIMPSI terhadap perubahan batas usia perkawinan (Studi atas Undang-Undang no 16 tahun 2019 tentang perubahan atas Undang-Undang No 1 Tahun 1974). Sedangkan data sekunder penelitian ini adalah buku dan jurnal. Data yang di peroleh ini sifatnya hanya mendukung.

Penelitian ini memilih penggalian informasi dengan membuat sejumlah pertanyaan terlebih dahulu yang sudah terstruktur. Dalam penelitian ini, wawancara diawali dengan pertanyaan-pertanyaan terkait dengan pandangan subjek terhadap perubahan batas usia perkawinan dan usia ideal untuk melaksanakan perkawinan. Kemudian hasil dari wawancara tersebut kemudian dianalisis. Sedangkan langkahlangkah menganalisis data adalah dengan memilih hal pokok, dan memfokuskan pada hal yang penting sehingga diperoleh gambaran yang jelas dan mempermudah peneliti menganalisis kemudian menyajikan data dalam bentuk uraian singkat dan sejenisnya karena ini penelitian kualitatif.

Faktor Kedewasaan Menurut Psikologi dan Perubahan Batas Usia Perkawinan

${ }^{7}$ Monks Monks, Siti Rahayu Haditono, Psikologi Perkembangan (Yogyakarta: Gajah Mada University Press, 2001), ,pp.333. 
Perubahan batas usia yang telah disebutkan dalam perubahan Undang-Undang perkawinan yang pada awalnya 16 tahun direvisi menjadi 19 tahun dalam kajian ilmu psikologi pada masa ini merupakan masa remaja. Pada masa ini seseorang masih dalam keadaan proses pertumbuhunan menuju kedewasaan. Kedewasaan dalam psikologi adalah kemampuan untuk merespon, mengatasi dan berpikir dengan cara yang sesuai dengan situasi dan tuntunan yang ada. Sedangkan pada masa remaja jika dilihat dari segi usia masih jauh dan belum dapat melakukan hal tersebut. Berdasarkan data dari Unite For Children (UNICEF) menyatakan bahwa masa remaja cenderung belum mampu mengolah emosi dan mengambil keputusan dengan baik. Apalagi memikul tanggung jawab sebagai pasangan suami istri tentunya tidak hanya merespon, mengatasi dan bernalar untuk diri sendiri melainkan juga untuk pasangan dan keluarga.

Adapun beberapa aspek yang mempengaruhi kedewasaan menurut psikologi adalah sebagai berikut : 8

\section{Aspek Kesehatan}

Berdasarkan aspek kesehatan pada usia 12 tahun pada umumnya anak perempuan sudah mengalami menarche (haid pertamanya) secara fisik dan reproduksi artinya sudah memasuki masa pubertas. Namun pada usia 19 tahun ke bawah sangat beresiko tinggi pada ibu dan janin saat melahirkan karena kondisi ibu yang belum siap secara fisik dalam melahirkan. Sehingga sangat berbahaya bagi kesehatan calon ibu dan calon bayi karena sistem reproduksi yang belum benar-benar matang akan berakibat pada kematian.

\section{Perkembangan Kognitif}

Pada perkembangan kognitifnya seseorang pada masa remaja terjadi perubahan di dalam aspek yang sama yakni perubahan mental, emosi, pola pikir dan perubahan perilaku. Mulai fokus pada diri sendiri, tidak terlalu bergantung pada kelompok, mulai fokus pada pola kerja, lebih tenang, sudah menemukan passionnya, kebutuhan untuk mandiri, kebutuhan untuk adanya pendamping hidup, dan membentuk rumah tangga. Namun, perkembangan kognitif manusia secara umum (seperti kemampuan berpikir logis, memahami norma dan perkembangan psikoseksual) biasanya dicapai ketika seseorang memasuki usia dewasa awal mengingat masa remaja hanya berpikir apa yang menurut dirinya benar tanpa memikirkan dampak yang terjadi dari keputusannya.

\section{Perkembangan Emosional}

Dalam perkembangan emosionalnya pada masa remaja peningkatan emosional dikenal dengan masa storm and stress, dimana remaja bisa merasakan sangat sedih kemudian bisa kembali bahagia dengan cepat atau sering juga disebut emosional yang bergejolak dan kurang stabil. Hal tersebut terjadi karena perubahan hormon yang terjadi pada masa remaja tentunya dengan emosional yang masih labil masa remaja lebih cenderung labil dalam menentukan keputusan. Berbeda dengan masa dewasa dimana emosional lebih stabil dan tidak mudah dipengaruhi oleh orang lain dalam menentukan keputusan. Maka oleh karena itu Dewasa merupakan seorang individu tidak lagi disebut sebagai masa tanggung (akil balig), tetapi sudah tergolong sebagai seorang

8 Sucipto, "Kedewasaan Dalam Akad Nikah Dalam Perspektif Interdispliner," Asas 6, no. 2 (2014): 3853,; Nurhadi M., Pendidikan Kedewasaan Dalam Perspektif Psikologi Islami, 2014; Muhammad Arif Hudaya, "Pengembangan Wakaf Di Pondok Modern Tazkka Batang: Studi Terhadap Pemikiran KH. Anang Rikza Masyhadi" (Universitas Islam Indonesia Yogyakarta, 2016). 
pribadi yang benar-benar dewasa (maturity). Dimana seseorang tidak lagi diperlakukan sebagai seorang anak atau remaja, tetapi sebagaimana layaknya seperti orang dewasa lainnya.

\section{Aspek Sosial}

Dari aspek sosial ada beberapa pandangan di masyarakat bahwa remaja laki-laki dituntut untuk menjadi kepala keluarga dan menafkahi keluarganya. Sementara remaja perempuan dituntut untuk membesarkan ukuran anak dan mengurus keluarga. walaupun secara psikologis mereka belum sepenuhnya siap untuk mengemban tanggung jawab tersebut. Di sisi lain jika pasangan suami istri remaja tidak dapat mempertahankan perkawinannya mereka dapat dikucilkan bahkan mendapat stigma yang tidak baik dari masyarakat. Sehingga pasangan suami istri remaja menjadi semakin sulit untuk mendapatkan dukungan yang mereka butuhkan dari orang-orang sekitar mereka.

\section{Aspek Pendidikan dan Ekonomi}

Sedangkan dari aspek pendidikan dan ekonomi perkawinan usia remaja berdampak suram terhadap masa depan dikarenakan pada usia 19 tahun seseorang baru menyelesaikan jenjang pendidikan tingkat SMA melihat kondisi zaman sekarang bahwa pendidikan sangat penting karena sulitnya lapangan pekerjaan sehingga akan berdampak pada hal lainya. Masalah ekonomi dalam rumah tangga serta dikarenakan minimnya tingkat pendidikan seringkali menjadi alasan pasangan suami istri remaja beralih ke gaya hidup yang tidak sehat. Akibatnya akan berpengaruh terhadap keluarga dan pertumbuhan anak. ${ }^{9}$

Berdasarkan analisis dari beberapa aspek tersebut mengenai kedewasaan di dalam perubahan Undang-Undang No 1 Tahun 1974 menjadi Undang-Undang No 16 Tahun 2019 yaitu pasal 7 ayat 1 bahwa usia untuk melakukan perkawinan adalah 19 tahun bagi perempuan merupakan hal yang positif. Mengingat pada usia 19 tahun seseorang sudah memasuki masa remaja akhir dimana pada usia tersebut kondisi psikologisnya dari berbagai aspek sudah mengalami perbaikan dari pada masa remaja awal. Namun untuk lebih relevan dalam melaksanakan perkawinan adalah pada usia 21-25 tahun, karena pada usia tersebut sudah memasuki masa kedewasaan dan memiliki kesiapan dalam aspek reproduksi, kognitif, emosional, sosial, ekonomi dan pendidikan. Sehingga pasangan yang akan melaksanakan perkawinan dapat menerapkan kehidupan rumah tangga yang sakinah, mawaddah, warohmah dan terlaksanakannya tujuan perkawinan.

Perubahan Undang-Undang tersebut tentunya tidak terlepas dari dampak negatif. Adapun dampak dari perubahan Undang-Undang batas usia perkawinan menurut perspektif psikologi adalah sebagai berikut:

\section{Tingginya Angka Perzinaan}

Perubahan Undang-Undang perkawinan tentunya tidak terlepas dari beberapa dampak negatif apabila pemerintah tidak melakukan banyak sosialisasi dan edukasi yang sejelas-jelasnya terhadap resiko perkawinan usia dini kepada seluruh lapisan masyarakat. Mengingat di zaman keterbukaan informasi seperti pornografi, pacaran

${ }^{9}$ Mappiare A, Psikologi Orang Dewasa Bagi Penyesuaian Dan Pendidikan (Surabaya: Usaha Nasional, 
dan pergaulan bebas di khawatirkan akan terjadi tingginya angka perzinaan yang dilakukan anak-anak berdasarkan keinginan mereka untuk segera menikah.

\section{Perkawinan Di bawah Tangan}

Tingginya angka perzinahan akan berdampak terhadap legalitas perkawinan. perkawinan dibawah tangan menjadi sasaran remaja yang tertolak untuk melakukan perkawinan karena masih di bawah umur yang dintukan oleh Undang-Undang. Akan banyak perkawinan di bawah tangan yang tidak tercatat di catatan sipil atau Pengadilan Agama yang mengakibatkan tidak terlindunginya hak-hak anak perempuan apabila terjadi masalah di dalam keluarga. Kemudian anak yang sudah terlanjur lahir akan sulit mendapat surat akta kelahiran untuk kepentingan daftar sekolah, kependudukan dan lain-lainya. Dengan demikian diharapkan sosialisasi dan edukasi dari pemerintah kepada masyarakat untuk melakukan dan melaksanakan Wacana sosialisasi "Jokawin Bocah" untuk membatasi lonjakan angka perkawinan usia dini.

Jadi untuk idealnya untuk melaksanakan perkawinan seseorang harus dianggap dewasa baik secara usia maupun psikisnya dan pemerintah harus lebih banyak melakukan sosialisasi dan edukasi terhadap masyarakat tentang perubahan UndangUndang ini dan tentang dampak dari perkawinan usia dini. Oleh karena itu konsolidasi antara pemerintah dan masyarakat diperlukan untuk hal ini agar terlaksanakannya tujuan perkawinan yaitu agar terciptanya kehidupan perkawinan yang sehat dan lebih baik lagi.

\section{Kesimpulan}

Berdasarkan pandangan HIMPSI Jawa Tengah terhadap perubahan UndangUndang batas usia perkawinan yang semula 16 tahun bagi perempuan menjadi 19 tahun sangatlah diperlukan. Hal ini dikarenakan pada usia 19 tahun calon pengantin sudah mengalami perkembangan psikologis yang lebih baik dari usia sebelumnya. Akan tetapi tataran ideal dalam melaksanakan perkawinan adalah usia 21-25 tahun karena pada usia tersebut sangat positif bagi kesiapan calon pengantin. Calon pengantin akan semakin matang secara pemikiran (kognitif), dengan pendidikan yang memadai, fisik, reproduksi, emosi dan peran sosial. Artinya calon pengantin sudah bekerja, sehingga calon pengantin baik laki-laki maupun perempuan benar-benar siap dalam melaksanakan tujuan perkawinan. Namun perubahan tersebut tidak terlepas dari beberapa dampak. Diantara dampaknya adalah dimungkinan dapat menyebabkan meningkatnya prilaku zina di kalangan remaja berdasarkan keinginan mereka untuk segera menikah. Tidak hanya itu dampak perubahan Undang-Undang ini juga dapat mengakibatkan bermunculannya perkawinan di bawah tangan yang tidak tercatat di catatan sipil maupun Pengadilan Agama yang akan diprediksi mengalami peningkatan.

\section{Daftar Pustaka}

A, Mappiare. Psikologi Orang Dewasa Bagi Penyesuaian Dan Pendidikan. Surabaya: Usaha Nasional, 1983.

Akbar, Ali. “Landasan Filosofis Dalam Dispensasi Nikah Dalam Uu No. 16 Tahun 2019.” Journal of Chemical Information and Modeling 53, no. 1-24 (2019): 1689-99.

Hudaya, Muhammad Arif. "Pengembangan Wakaf Di Pondok Modern Tazkka Batang:

Studi Terhadap Pemikiran KH. Anang Rikza Masyhadi." Universitas Islam 
Indonesia Yogyakarta, 2016.

Karlie, Ahmad Tholabi. Hukum Keluarga Indonesia. Jakarta: Sinar Grafika, 2013.

M., Nurhadi. Pendidikan Kedewasaan Dalam Perspektif Psikologi Islami, 2014.

Monks, Siti Rahayu Haditono, Monks. Psikologi Perkembangan. Yogyakarta: Gajah Mada University Press, 2001.

Octaviani, Fachria. “DAMPAK PERNIKAHAN USIA DINI TERHADAP PERCERAIAN DI INDONESIA," 2021.

https://journal.unpas.ac.id/index.php/humanitas/article/view/2820/1387.

Shaleh, Abdul Rahman. Psikologi Suatu Pengantar Dalam Presfektif Islam. Jakarta: Prenada Kencana, 2019.

Sucipto. "Kedewasaan Dalam Akad Nikah Dalam Perspektif Interdispliner." Asas 6, no. 2 (2014): 38-53. https://www.google.com/search?client=firefox-b$\mathrm{d} \& \mathrm{q}=$ Kedewasaan+Dalam+Akad+Nikah+Dalam+Perspektif+Interdispliner.

Sudarsono. Hukum Perkawinan Nasional. Jakarta: PT. Renika Cipta, 1991.

Yosepha, Pusparisa. “Jutaan Anak Perempuan Lakukan Permnikahan Dini," 2020. https://databoks.katadata.co.id/datapublish/2020/09/11/jutaan-anak-perempuanindonesia-lakukan-pernikahan-dini. 